\title{
Histamine H3 Receptor Antagonists Potentiate Methamphetamine Self-Administration and Methamphetamine-Induced Accumbal Dopamine Release
}

\author{
Patrik Munzar ${ }^{1,3,4}$, Gianluigi Tanda ${ }^{2,4}$, Zuzana Justinova ${ }^{1,4}$ and Steven R Goldberg*,1 \\ 'Preclinical Pharmacology Section, Behavioral Neuroscience Research Branch, Intramural Research Program, NIDA, NIH, Department of Health \\ and Human Services, Baltimore, MD, USA; ${ }^{2}$ Psychobiology Section, Medications Discovery Research Branch, Intramural Research Program, NIDA, \\ $\mathrm{NIH}$, Department of Health and Human Services, Baltimore, MD, USA
}

\begin{abstract}
Methamphetamine administration increases brain levels of histamine and neuronal histamine attenuates several of methamphetamine's behavioral effects. The role of different subtypes of histamine receptors in this negative feedback, however, remains unclear. There is some evidence on possible involvement of histamine $\mathrm{H} 3$ receptors in these actions of methamphetamine. The aim of the present study was to evaluate the effects of two histamine $\mathrm{H} 3$ receptor antagonists, clobenpropit and thioperamide, on rewarding and neurochemical effects of methamphetamine utilizing three in vivo methodologies, drug self-administration, drug discrimination, and microdialysis in Sprague-Dawley rats. In rats self-administering methamphetamine intravenously under a fixed-ratio schedule, presession treatment with thioperamide (1.0-3.0 mg/kg, subcutaneous, s.c.) or clobenpropit (1.0-3.0 mg/kg, s.c.) potentiated the reinforcing effects of methamphetamine, as indicated by a dose-dependent increase in responding for a low $0.03 \mathrm{mg} / \mathrm{kg}$ dose of methamphetamine, that by itself failed to maintain responding above saline substitution levels, and a decrease in responding for a higher $0.06 \mathrm{mg} / \mathrm{kg}$ training dose of methamphetamine. In contrast, neither thioperamide nor clobenpropit treatment increased responding during saline substitution. In other rats trained to discriminate intraperitoneal (i.p.) injection of $1.0 \mathrm{mg} / \mathrm{kg}$ methamphetamine from i.p. injection of saline, both thioperamide and clobenpropit $(0.3-3.0 \mathrm{mg} / \mathrm{kg}$, s.c.) dose dependently increased methamphetamine-appropriate responding when administered with a low $0.3 \mathrm{mg} / \mathrm{kg}$ i.p. dose of methamphetamine, which by itself produced predominantly saline-appropriate responding. However, thioperamide and clobenpropit produced only saline-appropriate responding when administered with saline vehicle. Finally, thioperamide and clobenpropit potentiated methamphetamine-induced elevations in extracellular dopamine levels in the shell of the nucleus accumbens, but did not increase brain dopamine levels when given alone. These findings point to histamine $\mathrm{H} 3$ receptors as a new and important receptor system modulating the reinforcing, subjective, and neurochemical actions of methamphetamine. Neuropsychopharmacology (2004) 29, 705-717, advance online publication, 21 January 2004; doi: I 0.1 038/sj.npp. 1300380
\end{abstract}

Keywords: methamphetamine; histamine; clobenpropit; thioperamide; self-administration; dopamine-microdialysis

\section{INTRODUCTION}

Methamphetamine is a highly abusable psychomotor stimulant with a wide range of behavioral actions that appear to be mediated primarily by stimulation of the

\footnotetext{
*Correspondence: Dr SR Goldberg, Preclinical Pharmacology Section, Behavioral Neuroscience Research Branch, Intramural Research Program, National Institute on Drug Abuse, National Institutes of Health, Department of Health and Human Services, 5500 Nathan Shock Drive, Baltimore, MD 21224, USA, Tel: 410550 1522, Fax: 410 550 1648, E-mail: sgoldber@intra.nida.nih.gov

${ }^{3}$ Present address: ALEXZA Molecular Delivery Corporation, Palo Alto, CA 94303, USA.

${ }^{4}$ These authors contributed equally to this work.

Received 23 July 2003; revised 04 December 2003; accepted 07 December 2003

Online Publication: 16 December 2003 at http://www.acnp.org/ citations/Npp I 2 160303323/default.pdf
}

dopamine neurotransmitter system (Kuczenski et al, 1995; Tidey and Bergman, 1998; Munzar and Goldberg, 2000). The behavioral actions of methamphetamine are, however, under the modulatory control of several nondopaminergic neurotransmitter systems, including serotonergic (Munzar et al, 1999a,b), noradrenergic (Munzar and Goldberg, 1999), adenosinergic (Munzar et al, 2002; Justinova et al, 2003), and histaminergic (Ito et al, 1996; Munzar et al, 1998) systems. The role of histaminergic receptors in the modulation of methamphetamine's behavioral and neurochemical effects is of particular interest, since methamphetamine releases histamine, as well as dopamine, and brain levels of histamine are markedly increased after methamphetamine administration (Ito et al, 1996).

It has been shown that methamphetamine-induced stereotyped behavior is attenuated under conditions of increased histamine levels (Ito et al, 1997) and recent findings in histamine $\mathrm{H} 3$-deficient mice (Toyota et al, 2002) suggest a possible modulatory role of $\mathrm{H} 3$ receptors 
in these effects. Histamine $\mathrm{H} 3$ receptors are expressed as autoreceptors on histaminergic neurons, with a negative feedback role on histamine synthesis and release (Arrang et al, 1983). Recently, however, it has been shown that these receptors are widely distributed on nonhistaminergic neurons and their activation can inhibit synthesis and release of other neurotransmitters, including dopamine, norepinephrine, GABA, and acetylcholine (Leurs et al, 1998). Histamine H3 receptors are particularly abundant in dopaminergic areas of the brain such as the nucleus accumbens in animals (Lovenberg et al, 1999; Pollard et al, 1993) and humans (Goodchild et al, 1999), the main terminal area of the mesolimbic dopamine system which plays a prominent role in the reinforcing/rewarding effects of methamphetamine and other psychomotor stimulant drugs abused by humans (Wise, 1987; Koob, 1992; Pontieri et al, 1995).

In a previous study, we reported that the selective histamine H3 antagonist thioperamide (Arrang et al, 1987) can potentiate the subjective effects of methamphetamine in rats trained to discriminate a $1.0 \mathrm{mg} / \mathrm{kg}$ intraperitoneal (i.p.) dose of methamphetamine from an i.p. injection of saline using a two-lever choice, drug-discrimination procedure, as demonstrated by a leftward shift in the methamphetamine dose-response curve when different doses of methamphetamine were coadministered with one dose of thioperamide (Munzar et al, 1998). This potentiation of methamphetamine's subjective effects by thioperamide was reversed by coadministering the histamine $\mathrm{H} 3$ agonist $R$ - $\alpha$-methylhistamine, demonstrating that the effects were mediated by histamine $\mathrm{H} 3$ receptors. In in vitro studies selective histamine $\mathrm{H} 3$ receptor antagonists can potentiate dopamine efflux in mouse striatum (Schlicker et $a l, 1993)$ and dopamine D1 receptor-dependent release of GABA in rat substantia nigra (Garcia et al, 1997) and striatum (Arias-Montano et al, 2001). Moreover, histamine H3 agonists inhibit the synthesis of dopamine in striatal areas and this is blocked by selective $\mathrm{H} 3$ antagonists, suggesting that endogenous histamine levels modulate dopamine synthesis (Schlicker et al, 1993; Molina-Hernandez et al, 2000). There is also a recent report that ciproxifan, another histamine $\mathrm{H} 3$ antagonist, can potentiate the effects of methamphetamine on neuropeptide mRNA expression in rat striatum (Pillot et al, 2003). Taken together, all these findings suggest $\mathrm{H} 3$ receptors exert a strong inhibitory modulation of dopamine-mediated behavioral and neurochemical effects of methamphetamine.

The aim of the present study was to evaluate the effects of histamine $\mathrm{H} 3$ antagonists on the reinforcing effects of methamphetamine, as measured by intravenous (i.v.) drug self-administration by rats, and on methamphetamineinduced dopamine release in the shell of the nucleus accumbens, as measured by in vivo microdialysis. Although thioperamide is the most commonly utilized histamine $\mathrm{H} 3$ antagonist, with high affinity at rat histamine $\mathrm{H} 3$ receptors, it has only modest affinity at human $\mathrm{H} 3$ receptors (Esbenshade et al, 2003). For this reason, in the present study, we tested effects not only of thioperamide, but also of clobenpropit, a potent histamine $\mathrm{H} 3$ antagonist, which shows approximately equal affinity for human and rat $\mathrm{H} 3$ receptors (eg Lovenberg et al, 2000; Esbenshade et al, 2003).

\section{MATERIALS AND METHODS}

\section{Subjects}

Male Sprague-Dawley rats (Taconic, Germantown, NY), experimentally naive at the start of the study and initially weighing 280-350 g, were housed either individually (for drug self-administration and drug-discrimination studies) or double-housed (for in vivo microdialysis studies). Rats used in drug-discrimination studies had their body weights gradually reduced to approximately $80 \%$ of free feeding by limiting daily access to food. Rats used in the selfadministration and microdialysis studies had free access to food. Water for all rats was available ad libitum. All rats were housed in a temperature- and humidity-controlled room and were maintained on a 12-h light/dark cycle (lights were on from 0700 to 1900). Experiments were conducted during the light phase.

Rats in the self-administration study were implanted with i.v. catheters, as described previously (Munzar et al, 1999a). Under Equithesin anesthesia, rats were prepared with a silastic catheter implanted into the external jugular vein, with the catheter exiting the skin at the back between the shoulders. A nylon bolt (screw thread \# 4-32) was embedded at the same time on the skull surface, fixed in place with dental acrylic to stainless-steel screws embedded in the skull. The nylon bolt served as a tether to prevent the catheter from being pulled out while the rat was in the selfadministration chamber. Following surgery, the i.v. catheter was flushed daily during the first week with $0.9 \%$ sterile saline containing heparin $(1.25 \mathrm{U} / \mathrm{ml})$ and gentamicin $(0.16 \mathrm{mg} / \mathrm{kg})$ and then flushed after each daily session with heparin solution to maintain its patency.

Rats in the microdialysis study were implanted during the same surgery with i.v. catheters and dialysis probes in the shell of the nucleus accumbens, as described previously (Pontieri et al, 1995; Tanda et al, 1997). Under Equithesin anesthesia, rats were first implanted with i.v. catheters, as described above, and then were placed in a stereotaxic apparatus where the skull was exposed and a small hole drilled to expose the dura. They were then implanted with a concentric dialysis probe aimed at the shell of the nucleus accumbens (Figure 1), according to the rat brain atlas by Paxinos and Watson (1986) (uncorrected coordinates: $\mathrm{A}=+2.0, \mathrm{~L}=1.1, \mathrm{~V}=8.0$; Anterior, $\mathrm{A}$, from bregma; Lateral, L, from bregma; Vertical, V, from dura).

Animals used in this study were maintained in facilities fully accredited by the American Association for the Accreditation of Laboratory Animal Care (AAALAC) and all experimentation was conducted in accordance with the guidelines of the Institutional Care and Use Committee of the Intramural Research Program, National Institute on Drug Abuse, NIH, and the Guide for Care and Use of Laboratory Animals (National Research Council, 1996).

\section{Apparatus}

A total of 22 standard experimental chambers (Coulbourn Instruments, Lehigh Valley, PA, USA), 12 for the drugdiscrimination study, and 10 for the drug self-administration study, were used. Each chamber in the discrimination study contained a white house light and two levers, 


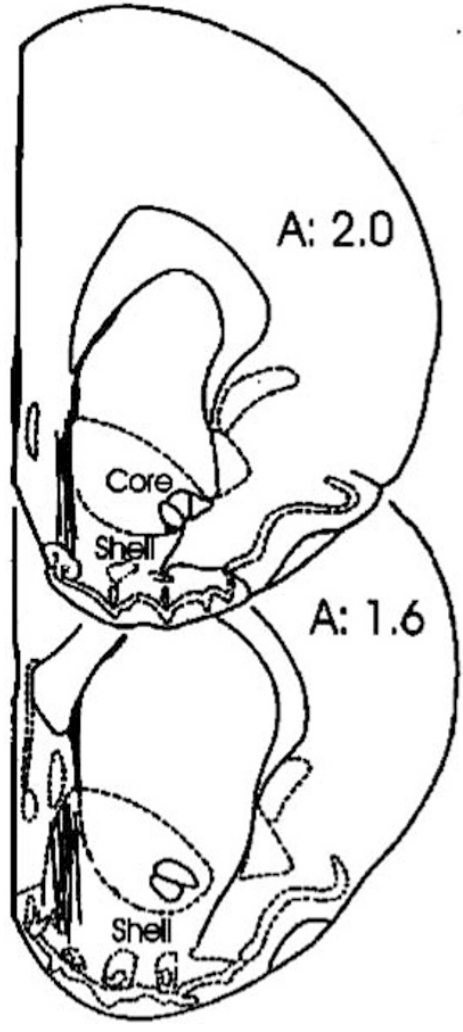

Figure I Brain histology. Forebrain sections representing the track corresponding to the dialyzing portion of the probes aimed at the shell of the nucleus accumbens. On both sections, the anterior coordinate (in millimeters, measured from bregma) is indicated.

separated by a recessed tray into which a pellet dispenser could deliver 45-mg food pellets (F0021; Bioserv, Frenchtown, NJ). Each press of a lever with a force of $0.4 \mathrm{~N}$ through $1 \mathrm{~mm}$ was recorded as a response and was accompanied by an audible click. Each chamber in the self-administration study contained a white house light and two holes containing nose-poke operanda. Each nose poke produced a brief feedback tone. One hole was defined as active (left in five chambers, right in remaining five) and pokes in the other hole were recorded but had no programmed consequences. Catheters were connected to an infusion pump (Harvard Apparatus, South Natick, MA, USA) through a tether and fluid swivel. All the operant chambers were controlled by microcomputers using the MED Associates MED-PC software package (Med Associates Inc., East Fairfield, VT).

For the in vivo microdialysis study, concentric dialysis probes were prepared with AN69 fibers (Hospal Dasco, Bologna, Italy) by a modification of the method described by Di Chiara et al (1993). Briefly, the components of the probe (the dialysing fiber and the two silica-fused capillary tubes) were inserted into a 22-G stainless-steel needle (2.4 mm length) and mounted in a stereotaxic holder. The resulting probe was of sufficient rigidity to make unnecessary the use of a tungsten mandrel to lower it into the brain (Tanda et al, 1997). The exposed dialysing surface of the fibers was limited to the lowest $2.0 \mathrm{~mm}$ of the probes. After implanting the microdialysis probes, rats were placed in hemispherical CMA-120 cages (CMA/Microdialysis AB, Solna, Sweden) equipped with overhead fluid swivels
(Instech Laboratories Inc., Plymouth Meeting, PA) for connections to the dialysis probes and allowed to recover overnight.

\section{Self-Administration Procedure}

After 7-10 days for complete recovery from surgery, daily (Monday-Friday) self-administration sessions started. During the 2-h sessions, rats had an opportunity to selfadminister $0.06 \mathrm{mg} / \mathrm{kg}$ i.v. injections of methamphetamine, as described previously (Munzar et al, 1999a; Stefanski et al, 1999). At the start of each session, one priming injection was delivered automatically, which was calculated to fill the 'dead volume' of the catheter. At the same time, the white house light was turned on. Rats initially learned to respond under a fixed-ratio 1 (FR1) schedule where each active nose poke produced a 2-s injection of the training dose of methamphetamine. The injection was followed by a $30-\mathrm{s}$ time-out, during which the chamber was dark and responding was recorded but had no programmed consequences. Once rats showed accuracy with at least $80 \%$ of the nose pokes in the active hole, and intake of methamphetamine was stable for 2 days, the number of responses required to produce an injection was increased progressively to two, three, and finally five (FR5).

Once number of injections per session was stable for at least five consecutive daily sessions under the FR5 schedule (less than $20 \%$ variability), testing of different doses of thioperamide, clobenpropit, or vehicle, given as subcutaneous (s.c.) injections $30 \mathrm{~min}$ before the start of a session, began. Test sessions were always conducted after at least two methamphetamine baseline sessions. Thioperamide and clobenpropit were tested in separate groups of rats. Subsequently, effects of two doses of thioperamide or clobenpropit and of their vehicle on the methamphetamine dose-response curve were evaluated. Finally, methamphetamine self-administration was reestablished at the $0.06 \mathrm{mg} /$ $\mathrm{kg}$ /injection training dose and thioperamide and clobenpropit were then tested by substitution for five consecutive sessions. The ratio of $1: 3$ between injection dose of methamphetamine and thioperamide and clobenpropit (0.06 vs $0.18 \mathrm{mg} / \mathrm{kg} /$ injection) was based on a previous finding that pretreatment with an i.p. dose of $1.0 \mathrm{mg} / \mathrm{kg}$ methamphetamine produced significant decreases in methamphetamine self-administration behavior (Munzar et al, 1999a) that were comparable to the decreases seen after s.c. pretreatment with $3.0 \mathrm{mg} / \mathrm{kg}$ thioperamide and clobenpropit in the present study.

\section{Drug-Discrimination Procedure}

Under a discrete-trial schedule of food-pellet delivery, rats learned to respond on one lever after an injection of a training dose of $1.0 \mathrm{mg} / \mathrm{kg}$ of methamphetamine and on the other lever after an injection of $1.0 \mathrm{ml} / \mathrm{kg}$ of saline vehicle, as described previously (Munzar et al, 1998, 1999a, b; Justinova et al, 2003). Injections of methamphetamine or saline were given i.p. $15 \mathrm{~min}$ before the start of the session. At the start of the session, a white house light was turned on and in its presence the rats were required to make 10 consecutive responses (FR10 schedule of food delivery; FR10) on the lever appropriate to the presession treatment. The 
completion of 10 consecutive responses on the correct lever produced delivery of a $45 \mathrm{mg}$ food pellet and initiated a $45-\mathrm{s}$ time-out during which lever-press responses had no programmed consequences and the chamber was dark. Responses on the incorrect lever had no programmed consequences other than to reset the FR requirement on the correct lever. After each time-out, the white house light was again turned on and the next trial began. Each session ended after completion of 20 FR trials or after $30 \mathrm{~min}$ elapsed, whichever occurred first.

Once rats learned to respond under the FR10 schedule of food delivery, discrimination training was started. Discrimination-training sessions were conducted 5 days per week under a double alternation schedule (ie DDSSDDSS etc, $\mathrm{D}=$ drug, $1.0 \mathrm{mg} / \mathrm{kg}$ methamphetamine; $\mathrm{S}=$ saline). Training continued until there were eight consecutive sessions during which rats completed at least $90 \%$ of their responses during the session on the correct lever and no more than four responses occurred on the incorrect lever during the first trial. Test sessions during which 10 consecutive responses on either one of the two levers ended the trial were then conducted about twice a week when different doses of thioperamide or clobenpropit were administered before the i.p. injection of either saline or a $0.3 \mathrm{mg} / \mathrm{kg}$ dose of methamphetamine and the percentage of methamphetamine-appropriate lever selections and rates of lever-press responding were measured. This experimental design differed from our previous study in which we tested effects of one thioperamide dose administered with different doses of methamphetamine (Munzar et al, 1998). We selected this dosing regimen in order to mimic the dosing regimen in self-administration studies, so that effects of the same doses of both histamine $\mathrm{H} 3$ antagonists on rates of responding for food and for self-administered methamphetamine could be compared. In a test phase, a single alternation schedule was introduced and test sessions were usually conducted on Tuesdays and Fridays. Thus, a 2-week sequence starting on Monday was: DTSDTSTDST ( $\mathrm{T}=$ test). In this way, test sessions occurred with equal probability after saline and drug sessions. Test sessions were conducted only if the criterion of $90 \%$ accuracy and not more than four incorrect responses during the first trial was maintained in the two preceding training sessions. Thioperamide and clobenpropit were tested in separate groups of rats. Injections of thioperamide, clobenpropit, or their vehicle (saline) were given s.c. $30 \mathrm{~min}$ before the session.

\section{In Vivo Microdialysis}

About $24 \mathrm{~h}$ after probe implant, experiments were performed on freely moving rats in the same hemispherical home cages in which they recovered overnight from surgery. Ringer's solution (147.0 mM NaCl, $2.2 \mathrm{mM} \mathrm{CaCl}_{2}$, and $4.0 \mathrm{mM} \mathrm{KCl}$ ) was delivered by a CMA 100 microdialysis pump (CMA/Microdialysis AB, Solna, Sweden) through the dialysis probes at a constant flow rate of $1 \mu \mathrm{l} / \mathrm{min}$. Collection of dialysate samples $(10 \mu \mathrm{l})$ started after $30 \mathrm{~min}$ and samples were taken every $10 \mathrm{~min}$ and immediately analyzed, as detailed below. After stable dopamine values (less than 10\% variability) were obtained for at least three consecutive samples (typically after about $1-2 \mathrm{~h}$ ), rats were treated with drug or saline. Injections of 1.0 or $3.0 \mathrm{mg} / \mathrm{kg}$ thioperamide,
$3.0 \mathrm{mg} / \mathrm{kg}$ clobenpropit, or saline were given s.c. $30 \mathrm{~min}$ before the i.v. injection of $0.03,0.06$, or $0.12 \mathrm{mg} / \mathrm{kg}$ methamphetamine. In a separate group of rats, thioperamide was applied locally in the shell of the accumbens through the microdialysis probe (reverse dialysis). In this experiment, thioperamide perfusion in the Ringer solution at two concentrations $(1.0$ and $10.0 \mu \mathrm{M})$ started $1 \mathrm{~h}$ before methamphetamine injection and continued until the end of the experiment.

Dialysate samples $(10 \mu \mathrm{l})$ were injected without purification into a high-performance liquid chromatography apparatus equipped with a MD $150 \mathrm{~mm} \times 3.2 \mathrm{~mm}$ column, particle size $3.0 \mu \mathrm{m}$ (ESA, Chelmsford, MA) and a Coulometric detector (5200a Coulochem II, ESA, Chelmsford, $\mathrm{MA})$ to quantify dopamine. The oxidation and reduction electrodes of the analytical cell (5014B, ESA, Chelmsford, $\mathrm{MA}$ ) were set at +125 and $-125 \mathrm{mV}$, respectively. The mobile phase, containing $100 \mathrm{mM} \mathrm{NaH}_{2} \mathrm{PO}_{4}, 0.1 \mathrm{mM} \mathrm{Na}$ EDTA, $0.5 \mathrm{mM} n$-octyl sodium sulfate, and $18 \%(\mathrm{v} / \mathrm{v})$ methanol ( $\mathrm{pH}$ adjusted to 5.5 with $\mathrm{Na}_{2} \mathrm{HPO}_{4}$ ), was pumped with an ESA 582 (ESA, Chelmsford, MA) solvent delivery module at $0.60 \mathrm{ml} / \mathrm{min}$. Assay sensitivity for dopamine was $2 \mathrm{fmol}$ per sample.

At the end of the experiment, rats were euthanized by pentobarbital overdose, brains were removed and left to fix in $4 \%$ formaldehyde in saline solution. Brains were then cut on a vibratome in serial coronal slices oriented according to the atlas by Paxinos and Watson (1986) in order to identify the location of the probes in relation to the shell of the nucleus accumbens (Figure 1).

\section{Drugs}

$S$ - (+ )-methamphetamine hydrochloride was obtained from NIDA (Rockville, MD, USA), thioperamide maleate was purchased from Sigma (St Louis, MO, USA) and clobenpropit dihydrobromide was purchased from Tocris (Tocris Cookson, Ellisville, MO, USA). Doses of all drugs refer to the salt. Drugs were dissolved in $0.9 \% \mathrm{NaCl}$ and were injected in a volume of $1.0 \mathrm{ml} / \mathrm{kg}$ as described above.

\section{Data Analysis}

In the self-administration study, results were expressed as a percentage of baseline responding or as total number of injections self-administered per session. Baseline responding was calculated as the average number of responses in the active hole within the three most recent methamphetamine baseline sessions. In the drug-discrimination study, results were expressed as the percentage of the total responses emitted on the methamphetamine-appropriate lever. Response-rate data were expressed as responses per second averaged over the session, with responding during time-out periods not included in calculations. In the microdialysis study, results were expressed as a percentage of basal dopamine values. Basal dopamine values were calculated as the mean of three consecutive samples (differing by no more than $10 \%$ ) immediately preceding the first drug or vehicle injection, with the exception of the reverse dialysis study where basal dopamine values were calculated as the mean of nine samples (three samples before the start of the infusion and six samples after the 
infusion of thioperamide) collected prior to injection of methamphetamine or its vehicle. All results are presented as group means $( \pm S E M)$.

Statistical analysis was carried out using one-way analysis of variance (ANOVA) for repeated measures followed by post hoc Dunnett's test for self-administration and drugdiscrimination studies. In microdialysis studies one- or two-way ANOVA for repeated measures over time was applied to the data obtained from serial assays of dialysate dopamine normalized as percentage of basal dopamine values of each group with results from treatments showing overall changes subjected to post hoc Tukey's test. Changes were considered to be significant when $p<0.05$ SigmaStat (Jandel Scientific, San Raphael, CA, USA) software was used.

\section{RESULTS}

\section{Self-Administration}

The effects of four doses of thioperamide or clobenpropit $(0.1,0.3,1,3 \mathrm{mg} / \mathrm{kg})$ and saline vehicle were first tested in rats trained to self-administer i.v. injections of $0.06 \mathrm{mg} / \mathrm{kg}$ methamphetamine. Thioperamide $\left(\mathrm{F}_{4,39}=16.40, p<0.001\right.$, Figure 2, upper panel) and clobenpropit $\left(\mathrm{F}_{4,16}=33.08\right.$, $p<0.001$, Figure 2, lower panel) produced similar dosedependent decreases in self-administration responding for the training dose of methamphetamine that were most pronounced at the higher 1 and $3 \mathrm{mg} / \mathrm{kg}$ doses.

Doses of 1 and $3 \mathrm{mg} / \mathrm{kg}$ thioperamide significantly decreased numbers of self-administered $0.06 \mathrm{mg} / \mathrm{kg}$ methamphetamine injections $\left(\mathrm{F}_{2,12}=14.52, p<0.001\right.$, Figure $\left.3 \mathrm{c}\right)$. Doses of 1 and $3 \mathrm{mg} / \mathrm{kg}$ thioperamide also significantly decreased self-administration responding for a higher $0.12 \mathrm{mg} / \mathrm{kg} /$ injection dose of methamphetamine $\left(\mathrm{F}_{2,10}=13.42\right.$, $p=0.001$, Figure $3 \mathrm{~d}$ ). When the injection dose of selfadministered methamphetamine was reduced from 0.06 to $0.03 \mathrm{mg} / \mathrm{kg}$ and self-administration responding was almost completely eliminated, however, pretreatment with 1 and $3 \mathrm{mg} / \mathrm{kg}$ thioperamide $\left(\mathrm{F}_{2,9}=8.09, \quad p=0.01\right)$ produced marked, dose-dependent increases in self-administration of methamphetamine (Figure 3b). In contrast, when selfadministration responding was almost completely eliminated by substitution of saline for methamphetamine, presession treatment with thioperamide did not increase (reinstate) responding (Figure $3 a$ ).

Doses of 1 and $3 \mathrm{mg} / \mathrm{kg}$ clobenpropit also significantly decreased numbers of self-administered $0.06 \mathrm{mg} /$ $\mathrm{kg}$ methamphetamine injections $\left(\mathrm{F}_{2,8}=27.62, p<0.001\right.$, Figure 4c). When the injection dose of self-administered methamphetamine was reduced from 0.06 to $0.03 \mathrm{mg} / \mathrm{kg}$ and self-administration responding was almost completely eliminated, however, pretreatment with 1 and $3 \mathrm{mg} / \mathrm{kg}$ clobenpropit $\left(\mathrm{F}_{2,7}=14.27, p=0.003\right)$ produced marked, dose-dependent increases in self-administration of methamphetamine (Figure 4b). In contrast, when self-administration responding was almost completely eliminated by substitution of saline for methamphetamine, presession treatment with clobenpropit did not increase (reinstate) responding (Figure 4a).

Representative cumulative-response records of a rat under the FR schedule at different injection doses of
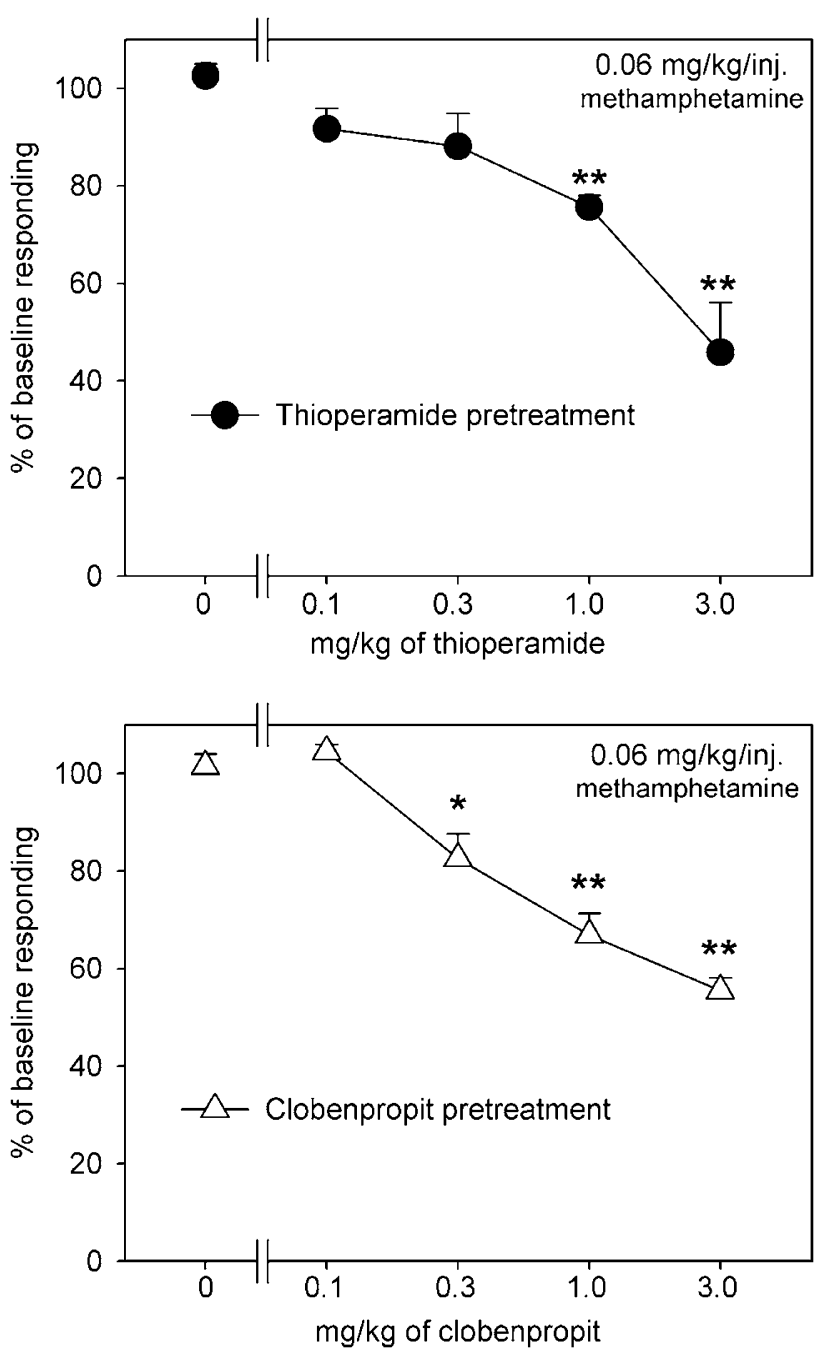

Figure 2 Effects of thioperamide and clobenpropit on self-administration of the training dose of methamphetamine. Effects of thioperamide and clobenpropit s.c. pretreatment on percentage of baseline responding during methamphetamine $(0.06 \mathrm{mg} / \mathrm{kg} /$ injection $)$ self-administration in rats. Values at different doses of thioperamide (filled circles, upper panel) or clobenpropit (open triangles, lower panel) are expressed as a mean ( \pm SEM) from $n=10-1 \mid$ (thioperamide) or $n=5$ (clobenpropit) subjects. ${ }^{*} p<0.05$, ** $p<0.01$, post hoc comparisons with the vehicle control after significant one-way ANOVA for repeated measures main effect, Dunnett's test.

methamphetamine or saline vehicle under baseline conditions and on days when the rat was treated with $3 \mathrm{mg} / \mathrm{kg}$ i.p. of clobenpropit $30 \mathrm{~min}$ before the session are shown in Figure 5. When self-administration responding was reduced to three injections and 18 responses per session by substitution of saline for methamphetamine, clobenpropit pretreatment did not increase the number of injections or responses in the session. Self-administration responding was also reduced under baseline conditions at the low $0.03 \mathrm{mg} / \mathrm{kg} /$ injection dose of methamphetamine, with only four injections of methamphetamine self-administered and 22 responses in the session. When clobenpropit was given before the session, however, the number of $0.03 \mathrm{mg} / \mathrm{kg}$ methamphetamine injections in the session increased to 32 and the number of responses in the session increased to 

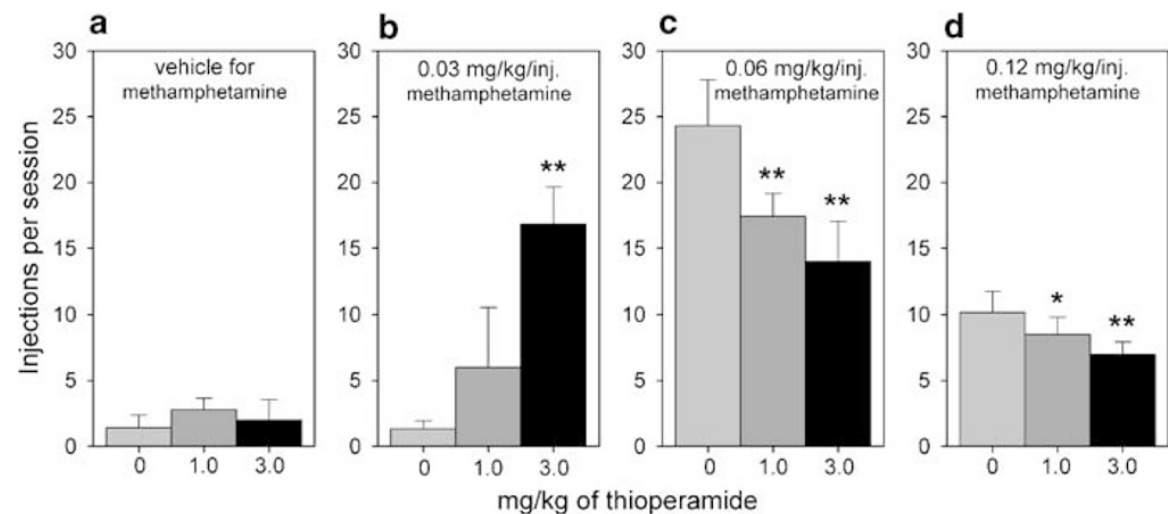

Figure 3 Effects of thioperamide on self-administration of different doses of methamphetamine. Effects of s.c. pretreatment with thioperamide on numbers of i.v. injections per session of different doses of methamphetamine: (a) vehicle, (b) $0.03 \mathrm{mg} / \mathrm{kg} / \mathrm{injection}$, (c) $0.06 \mathrm{mg} / \mathrm{kg} / \mathrm{injection}$, and (d) $0.12 \mathrm{mg} /$ $\mathrm{kg} /$ injection. Each point represents the mean $( \pm \mathrm{SEM})$ from $n=5-7$ subjects. ${ }^{*} p<0.05, * * * 0.01$, post hoc comparisons with the vehicle control after significant one-way ANOVA for repeated measures main effect, Dunnett's test.
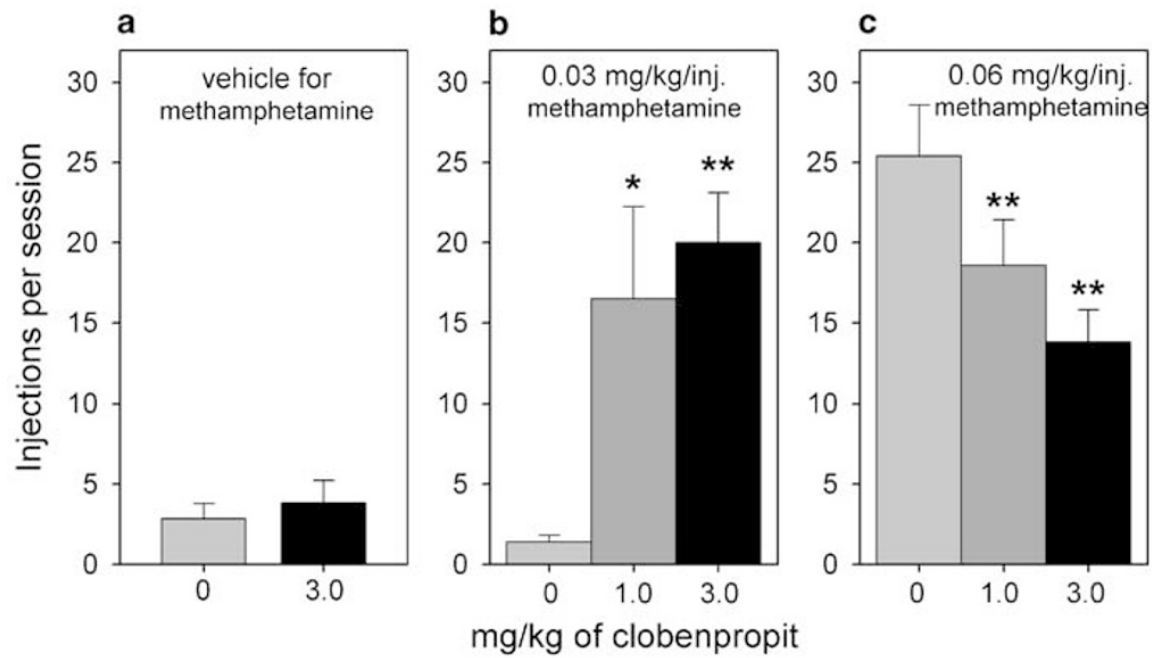

Figure 4 Effects of clobenpropit on self-administration of different doses of methamphetamine. Effects of s.c. pretreatment with clobenpropit on numbers of i.v. injections per session of different doses of methamphetamine: (a) vehicle, (b) $0.03 \mathrm{mg} / \mathrm{kg} / \mathrm{injection}$, and (c) $0.06 \mathrm{mg} / \mathrm{kg} / \mathrm{injection}$. Each point represents the mean $( \pm S E M)$ from $n=5$ subjects. ${ }^{*} p<0.05$, $* * p<0.01$, post hoc comparisons with the vehicle control after significant one-way ANOVA for repeated measures main effect, Dunnett's test.

160. In contrast, under baseline conditions at the higher $0.06 \mathrm{mg} / \mathrm{kg} /$ injection training dose of methamphetamine, 27 injections of methamphetamine were self-administered and the number of responses in the session was 135 . When clobenpropit was given before the session, the number of methamphetamine injections in the session decreased to 15 and the number of responses decreased to 75 .

When i.v. injections of $0.18 \mathrm{mg} / \mathrm{kg}$ thioperamide or clobenpropit were substituted for injections of $0.06 \mathrm{mg} / \mathrm{kg}$ methamphetamine for 5 days, neither thioperamide $\left(\mathrm{F}_{5,20}=13.082, p<0.001\right)$ nor clobenpropit $\left(\mathrm{F}_{5,15}=10.604\right.$, $p<0.001)$ were self-administered above saline-substitution levels (Figure 6). On the first day of substitution, rats selfadministered on average $1.98 \pm 0.45 \mathrm{mg} / \mathrm{kg}$ of thioperamide or $1.31 \pm 0.56 \mathrm{mg} / \mathrm{kg}$ of clobenpropit i.v., which is in the range of doses which potentiated the reinforcing effects of methamphetamine when given s.c., but during subsequent sessions self-administration responding almost completely ceased. Self-administration responding immediately recov- ered when thioperamide or clobenpropit were replaced with methamphetamine.

\section{Drug Discrimination}

When the range of doses of thioperamide and clobenpropit tested in rats self-administering methamphetamine was tested in parallel groups of rats responding for food and trained to discriminate i.p. injections of $1.0 \mathrm{mg} / \mathrm{kg}$ methamphetamine from i.p. injections of saline, neither thioperamide nor clobenpropit produced any change in rates of food-maintained responding (Figure $7 \mathrm{~b}$, filled symbols). Thioperamide and clobenpropit also did not produce any methamphetamine-appropriate responding with the drugdiscrimination procedure (Figure $7 \mathrm{a}$, filled symbols). In contrast, when either thioperamide or clobenpropit were coadministered with a subthreshold i.p. dose of methamphetamine $(0.3 \mathrm{mg} / \mathrm{kg})$, which by itself produced only 


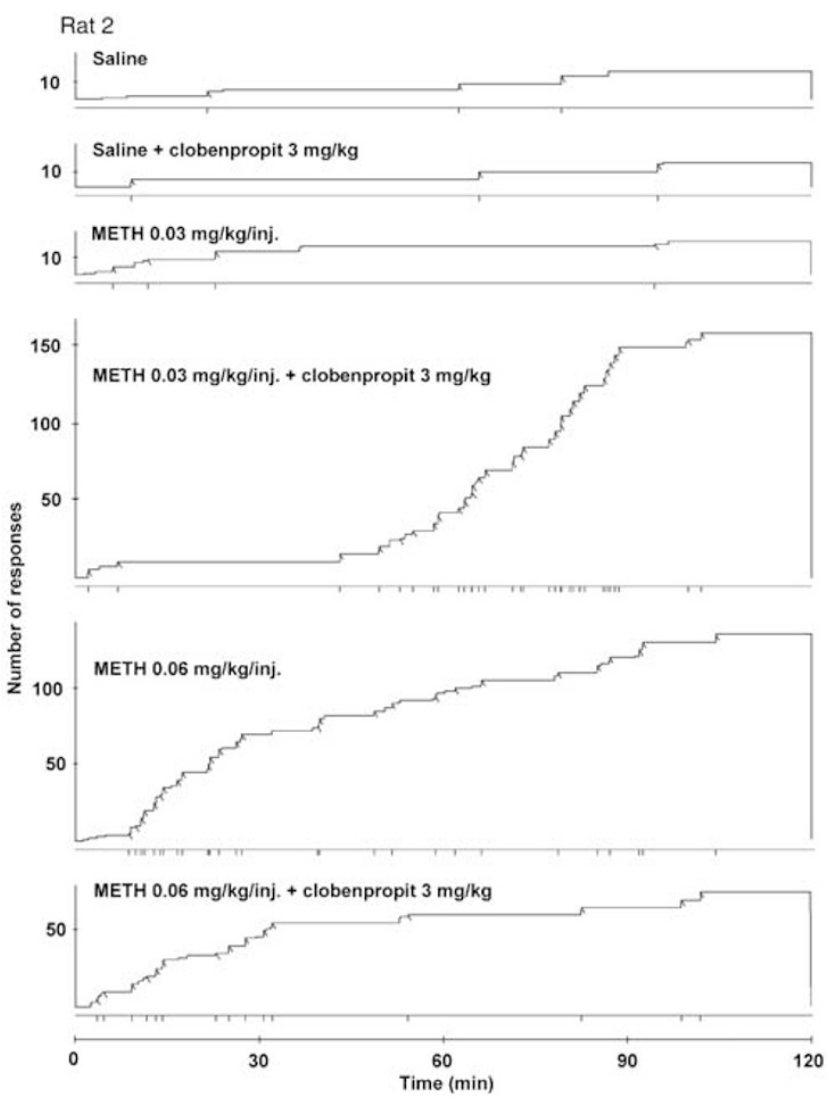

Figure 5 Representative cumulative-response records and injection event records of methamphetamine self-administration under the FR schedule. Records show self-administration of doses 0 (Saline), 0.03, and $0.06 \mathrm{mg} / \mathrm{kg} /$ injection of methamphetamine after pretreatment with saline vehicle or $3 \mathrm{mg} / \mathrm{kg}$ clobenpropit under the FR5 schedule of drug injection. Records represent the last of three to four sessions with vehicle pretreatment and a single subsequent session with s.c. clobenpropit pretreatment for each methamphetamine dose condition. Ordinates represent cumulative number of nose-poke responses and abscissas represent time. Short diagonal marks on the cumulative records and on the horizontal event lines under each record indicate drug injections.

saline-appropriate responding with the drug-discrimination procedure and no change in rates of responding, there were dose-dependent increases in methamphetamine-appropriate responding (thioperamide: $\mathrm{F}_{4,44}=16.319, p<0.001$; clobenpropit: $\mathrm{F}_{4,36}=13.123, p<0.001$; Figure $7 \mathrm{a}$, open symbols). In addition, thioperamide slightly, but significantly $\left(\mathrm{F}_{4,44}=4.535, p=0.004\right)$, enhanced rates of operant responding for food when coadministered with the lowest methamphetamine dose (Figure $7 \mathrm{~b}$, open circles).

\section{In Vivo Microdialysis}

In order to determine whether changes in the extracellular levels of dopamine correlate with the changes in the rewarding and subjective effects of methamphetamine produced by blockade of histamine $\mathrm{H} 3$ receptors, extracellular dopamine levels in the shell of the nucleus accumbens were measured in a parallel group of rats. Basal levels of dopamine in $10 \mu \mathrm{l} /$ dialysate samples were $48.86 \pm 7.6$ (fmol \pm SEM, $n=71$ ). Basal values did not differ between treatment groups (one-way ANOVA $F_{15,55}=0.216$,
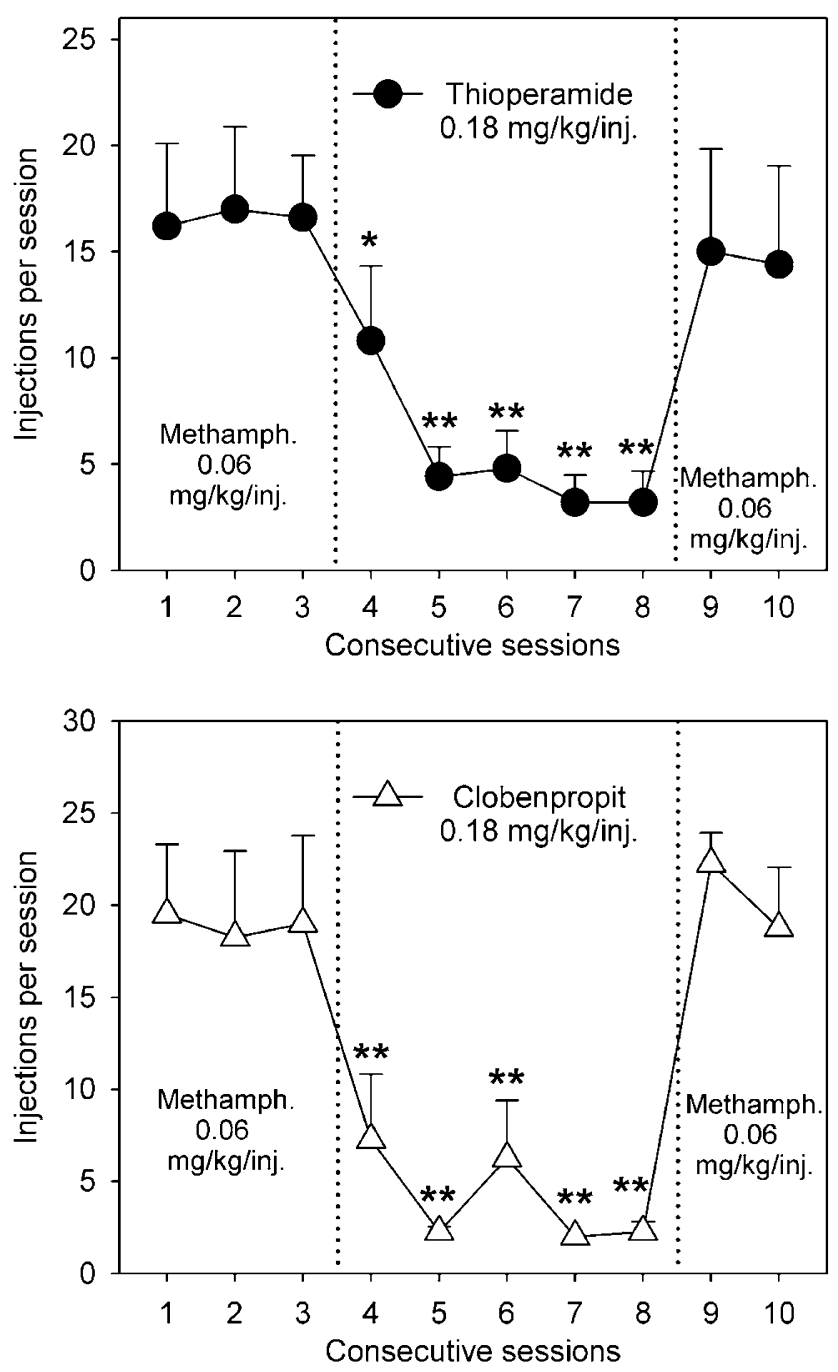

Figure 6 Substitution of histamine $\mathrm{H} 3$ antagonists for self-administered methamphetamine. Thioperamide $(0.18 \mathrm{mg} / \mathrm{kg} /$ injection; upper panel) and clobenpropit $(0.18 \mathrm{mg} / \mathrm{kg} /$ injection; lower panel) substitution (sessions four to eight) in rats trained to self-administer methamphetamine $(0.06 \mathrm{mg} / \mathrm{kg} /$ injection). Each point represents the mean $( \pm$ SEM) from $n=4-5$ subjects. $* p<0.05$, ** $p<0.0$ I, post hoc comparisons with the last methamphetamine self-administration session before thioperamide or clobenpropit substitution (session three) after significant one-way ANOVA for repeated measures main effect, Dunnett's test.

$p=0.99$ ). Administration of either 1.0 or $3.0 \mathrm{mg} / \mathrm{kg}$ s.c. doses of thioperamide did not significantly modify extracellular dopamine levels, that is, dopamine levels did not differ $\pm 10 \%$ from basal values during the first 30 min after injection (Figure 8). A subsequent saline injection did not significantly modify dopamine levels up to $2 \mathrm{~h}$ after its administration (data not shown). However, when 1.0 or $3.0 \mathrm{mg} / \mathrm{kg}$ s.c. doses of thioperamide (Figure 8) were administered $30 \mathrm{~min}$ before methamphetamine $(0.03,0.06$, or $0.12 \mathrm{mg} / \mathrm{kg}$ i.v.), there was a marked and significant potentiation of methamphetamine-induced elevations of dopamine levels in the shell of the accumbens (two-way ANOVA for repeated measures, time $\times$ thioperamide interaction: $0.03 \mathrm{mg} / \mathrm{kg}$ group $-\mathrm{F}_{6,56}=14.6605, p<0.01$; $0.06 \mathrm{mg} / \mathrm{kg}$ group $-\mathrm{F}_{18,120}=3.545, \quad p<0.02 ;$ and in $0.12 \mathrm{mg} / \mathrm{kg}$ group $\left.-\mathrm{F}_{24,195}=2.128, p<0.01\right)$. 

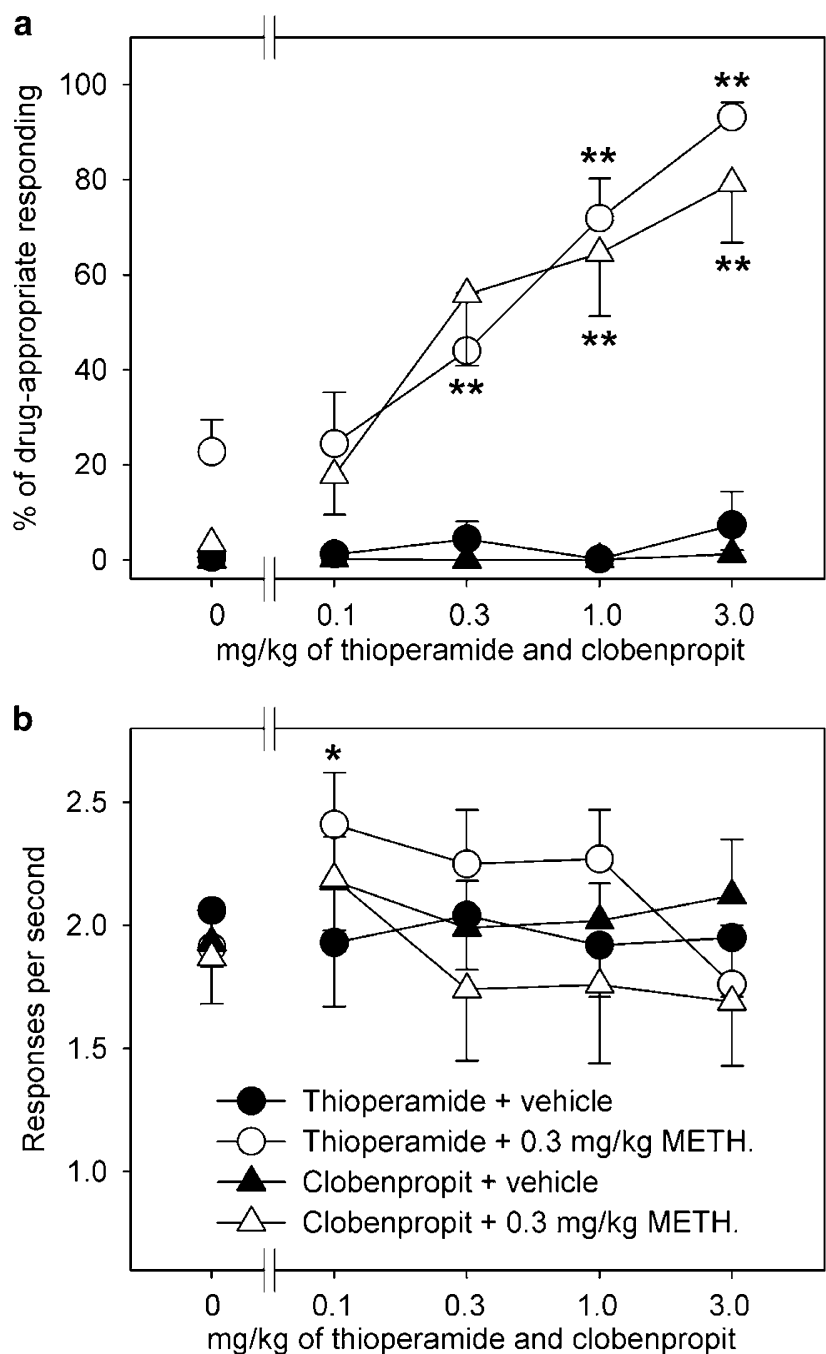

Figure 7 Effects of thioperamide and clobenpropit on methamphetamine discrimination. (a) Percentages of methamphetamine-appropriate lever selection and (b) rates of responding following s.c. pretreatment with thioperamide (circles) or clobenpropit (triangles) in rats trained to discriminate $1.0 \mathrm{mg} / \mathrm{kg}$ of methamphetamine, i.p. from saline. Thioperamide and clobenpropit were administered either with vehicle (filled symbols) or with $0.3 \mathrm{mg} / \mathrm{kg}$ methamphetamine (open symbols). Each point represents the mean $( \pm$ SEM) from $n=5-12$ subjects. $* p<0.05$, $* *$ $p<0.0$ l, post hoc comparisons with the vehicle control after significant one-way ANOVA for repeated measures main effect, Dunnett's test.

Administration of a $3.0 \mathrm{mg} / \mathrm{kg}$ s.c. dose of clobenpropit did not significantly modify basal extracellular dopamine levels during the first $30 \mathrm{~min}$ after injection (Figure 9), and a subsequent saline injection did not significantly modify dopamine levels up to $2 \mathrm{~h}$ after its administration (data not shown). Clobenpropit $(3.0 \mathrm{mg} / \mathrm{kg}$ s.c.) (Figure 9) administered $30 \mathrm{~min}$ before methamphetamine $(0.03$ or $0.06 \mathrm{mg} / \mathrm{kg}$ i.v.) markedly and significantly potentiated methamphetamine-induced elevations of dopamine levels in the shell of the accumbens (two-way ANOVA for repeated measures, time $\times$ clobenpropit interaction: $0.03 \mathrm{mg} / \mathrm{kg} \quad$ group $-\mathrm{F}_{6,56}=6.068, \quad p<0.01 ; \quad 0.06 \mathrm{mg} / \mathrm{kg}$ group $-\mathrm{F}_{9,80}=9.546, p<0.01$ ).

Thioperamide was subsequently directly infused into the shell of the nucleus accumbens by reverse dialysis

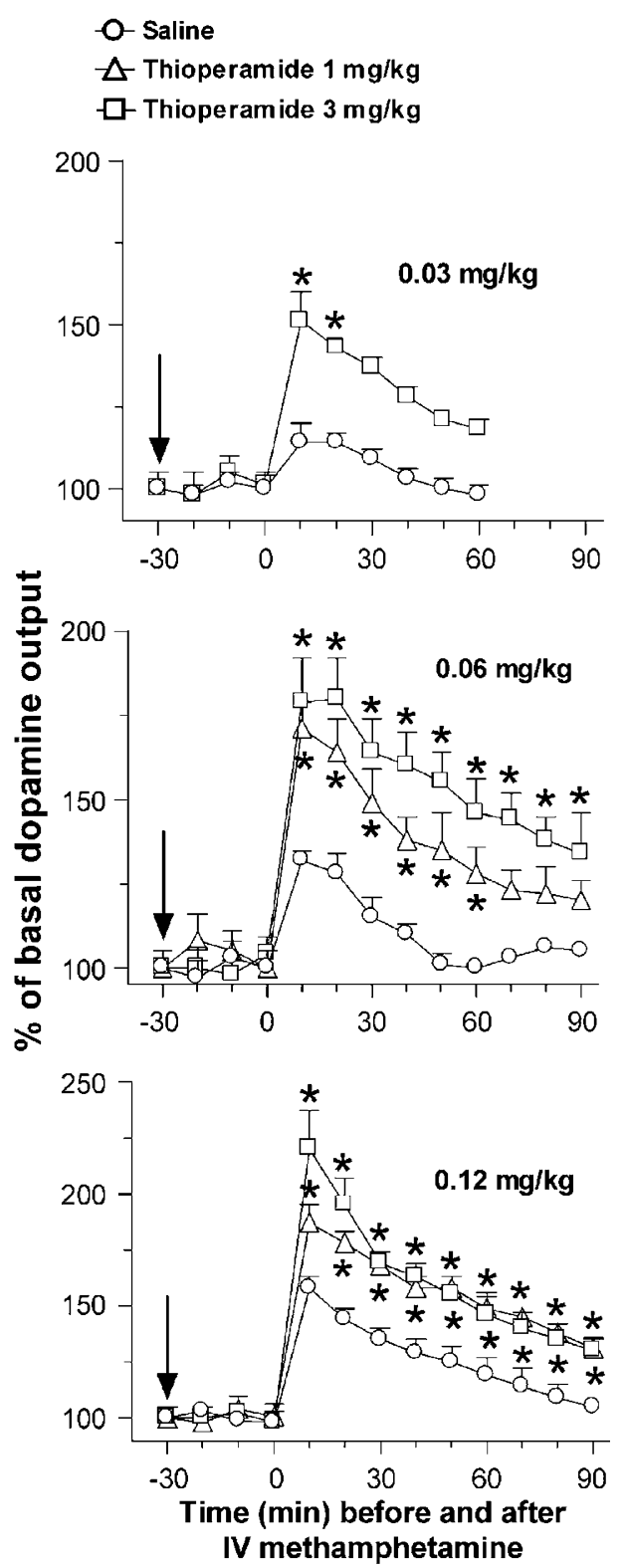

Figure 8 Effects of thioperamide pretreatment on methamphetamineinduced dopamine release in vivo. Effects of s.c. pretreatment with thioperamide $(1.0$ and $3.0 \mathrm{mg} / \mathrm{kg})$ or saline $(1.0 \mathrm{ml} / \mathrm{kg})$, administered $30 \mathrm{~min}$ before methamphetamine (indicated by arrow), on dialysate dopamine in the nucleus accumbens stimulated by i.v. injection of methamphetamine (0.03, top panel; 0.06, middle panel; and $0.12 \mathrm{mg} / \mathrm{kg}$, bottom panel). Results are means \pm SEM of the amount of dopamine obtained in 10-min dialysate samples expressed as percentage change from basal values (collected before thioperamide or saline pretreatment), uncorrected for probe recovery $(n=5$ rats per group for each drug/dose condition, with the exception of saline + methamphetamine $0.12 \mathrm{mg} / \mathrm{kg}$ $n=7$ and thioperamide $1 \mathrm{mg} / \mathrm{kg}$ + methamphetamine $0.12, n=6$ ). *p $<0.05$ (Tukey's post hoc test after two-way ANOVA for repeated measures) compared with the corresponding value for saline controls.

through the microdialysis probe (Figure 10). Local infusion with thioperamide (1.0 and $10.0 \mu \mathrm{M}$ in Ringer solution) did not significantly modify extracellular dopamine levels (changes were $< \pm 10 \%$ of baseline levels) in the nucleus accumbens shell up to $180 \mathrm{~min}$ after the infusion (data not shown). However, as after systemic administration, 


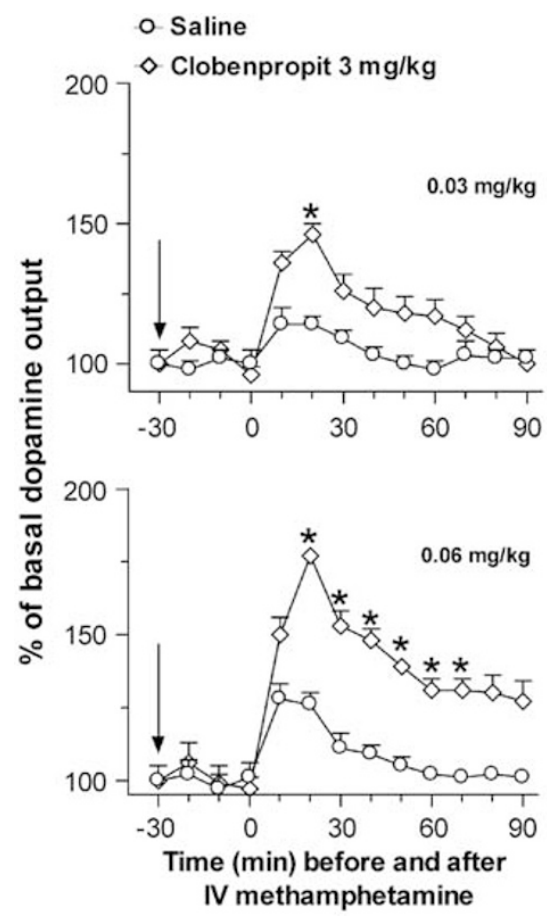

Figure 9 Effects of clobenpropit pretreatment on methamphetamineinduced dopamine release in vivo. Effects of s.c. pretreatment with clobenpropit $(3.0 \mathrm{mg} / \mathrm{kg})$ or saline $(1.0 \mathrm{ml} / \mathrm{kg})$, administered $30 \mathrm{~min}$ before methamphetamine (indicated by arrow), on dialysate dopamine in the nucleus accumbens stimulated by i.v. injection of methamphetamine $(0.03 \mathrm{mg} / \mathrm{kg}$, top panel and $0.06 \mathrm{mg} / \mathrm{kg}$, bottom panel). Results are means + SEM of the amount of dopamine obtained in 10-min dialysate samples expressed as percentage change from basal values (collected before clobenpropit or saline pretreatment), uncorrected for probe recovery. The $n=5$ rats per group for each drug/dose condition. * $p<0.05$ (Tukey's post hoc test after two-way ANOVA for repeated measures) compared with the corresponding value for saline controls.

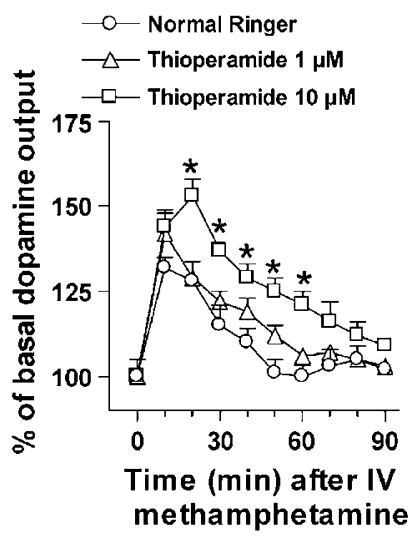

Figure 10 Effects of locally administered thioperamide on methamphetamine-induced dopamine release in vivo. Effects of thioperamide dissolved in Ringer solution (vehicle, $n=5 ; 1.0 \mu M, n=4 ; 10 \mu M, n=4$ ), perfused locally through the microdialysis probe with reverse dialysis, on dialysate dopamine levels in the nucleus accumbens after i.v. injection of $0.06 \mathrm{mg} / \mathrm{kg}$ methamphetamine. Infusion of thioperamide or its vehicle started $60 \mathrm{~min}$ before i.v. injection of methamphetamine and continued till the end of experiment. Results are means \pm SEM of the amount of dopamine obtained in I0-min dialysate samples expressed as percentage change from basal values uncorrected for probe recovery. ${ }^{*} p<0.05$ (Tukey's post hoc test after two-way ANOVA for repeated measures) compared with the corresponding value for normal Ringer controls. local infusion with thioperamide $(10 \mu \mathrm{M}$ in the Ringer solution) significantly potentiated dopamine release induced by methamphetamine, $0.06 \mathrm{mg} / \mathrm{kg}$ i.v. (two-way ANOVA for repeated measures: $\left.F_{9,72}=2.060, p<0.05\right)$, in the nucleus accumbens shell.

\section{DISCUSSION}

The main finding of the present study is that histamine H3 receptor antagonists can potentiate the reinforcing and discriminative actions of methamphetamine and that this is associated with a potentiation by the histamine $\mathrm{H} 3$ antagonists of methamphetamine-induced dopamine release in the shell of the nucleus accumbens. The selective histamine $\mathrm{H} 3$ receptor antagonists thioperamide and clobenpropit both dose dependently increased self-administration of a low $0.03 \mathrm{mg} / \mathrm{kg}$ injection dose of methamphetamine and reduced self-administration of a higher dose of $0.06 \mathrm{mg} / \mathrm{kg} /$ injection of methamphetamine. The reductions in self-administration of the higher training dose of $0.06 \mathrm{mg} / \mathrm{kg} /$ injection methamphetamine produced by the histamine $\mathrm{H} 3$ antagonists were similar to the reduction in self-administration seen when the injection dose of methamphetamine was simply increased from 0.06 to $0.12 \mathrm{mg} / \mathrm{kg}$. Also, increases in self-administration of the low dose of methamphetamine produced by the histamine H3 antagonists were similar to the increase in selfadministration seen when the injection dose of methamphetamine was raised from 0.03 to $0.06 \mathrm{mg} / \mathrm{kg}$. Thus, the changes in methamphetamine self-administration produced by histamine $\mathrm{H} 3$ antagonist treatment were consistent with a classical shift to the left of the 'inverted U-shaped' methamphetamine dose-response curve and were likely due to a potentiation of methamphetamine's efficacy as a reinforcer across the different doses studied. Also, the potentiation of the reinforcing effects of a low dose of methamphetamine that maintained little behavior on its own was not due to a reinstatement by histamine H3 antagonists of drug-seeking behavior that had been extinguished, since neither thioperamide nor clobenpropit reinstated drug-seeking behavior when given during saline extinction.

The same doses of the histamine $\mathrm{H} 3$ antagonists that increased self-administration of a low dose of methamphetamine also dose dependently potentiated both the discriminative effects of a low dose of methamphetamine and the elevations in dopamine levels in the shell of the nucleus accumbens produced by low doses of methamphetamine. However, when these doses of thioperamide and clobenpropit were given alone, they had no effect on food-maintained responding, which is consistent with both our previous drug-discrimination study (Munzar et al, 1998) and previous studies showing that thioperamide does not decrease locomotor activity (Clapham and Kilpatrick, 1994; Komater et al, 2003). Thus, the effects of the histamine $\mathrm{H} 3$ antagonists on methamphetamine selfadministration were not due to nonspecific effects on appetitive responding nor to direct effects on locomotor activity. Also, when these doses of thioperamide and clobenpropit were given alone, they did not produce methamphetamine-like discriminative effects, did not alter 
dopamine levels in the shell of the nucleus accumbens and, as noted above, did not reinstate drug-seeking behavior when given during saline extinction. This makes it unlikely that the histamine $\mathrm{H} 3$ antagonists had any effects that were discriminated as methamphetamine-like, which could have enhanced the actions of low doses of methamphetamine in an additive manner.

Although thioperamide and clobenpropit showed equal potency in potentiating the reinforcing and discriminativestimulus effects of methamphetamine, clobenpropit is about 10 -fold more potent than thioperamide as a histamine $\mathrm{H} 3$ antagonist when studied in vitro (Lovenberg et al, 2000; Esbenshade et al, 2003). However, clobenpropit has poor brain penetration which limits its bioavailability and markedly diminishes its in vivo activity (eg Krause et al, 1998; Stark et al, 2001). This likely accounts for the similarity in potency of clobenpropit and thioperamide in the present in vivo study.

The reinforcing and discriminative effects of methamphetamine in experimental animals are believed to be mainly mediated by its ability to interact with the dopaminergic system (eg Tidey and Bergman, 1998; Munzar et al, 1999a; Munzar and Goldberg, 2000). Based on our findings that histamine $\mathrm{H} 3$ receptor antagonists potentiate the discriminative and reinforcing effects of methamphetamine, we explored the possibility that $\mathrm{H} 3$ receptor antagonists could also alter its related dopaminergic actions in areas of the brain mediating these behaviors. Although histamine $\mathrm{H} 3$ receptors are located in many brain areas, one area of the human brain with particularly high densities of histamine $\mathrm{H} 3$ receptors is the nucleus accumbens (Goodchild et al, 1999). An increase in histamine levels in the nucleus accumbens after methamphetamine administration has been demonstrated (Ito et al, 1996; Morisset et al, 2002), and it is likely the result of increased endogenous dopaminergic tone on dopaminergic nerve terminals of VTA and substantia nigra dopamine neurons that project to the tuberomamillary nucleus (Ericson et al, 1989), activation of postsynaptic dopamine D2 receptors located on histaminergic neurons (Prast et al, 1993; Ito et al, 1996), and facilitation of histamine release from histaminergic nerve terminals of the nucleus accumbens.

The shell of the nucleus accumbens is also the main terminal area of the mesolimbic dopaminergic brain reward system and has been implicated in motivational and reinforcing effects of drugs abused by humans (Alheid and Heimer, 1988; Heimer et al, 1991; Pontieri et al, 1995). Many drugs abused by humans, including methamphetamine, share the common property of preferentially increasing dopamine release in the shell of the nucleus accumbens (Di Chiara et al, 1999). When given alone neither thioperamide nor clobenpropit produced any change in extracellular levels of dopamine in the shell of the nucleus accumbens. This is consistent with the present behavioral findings that thioperamide and clobenpropit did not increase drug self-administration responding during saline extinction and did not produce methamphetamine-like discriminative-stimulus effects when given alone. Both thioperamide and clobenpropit, however, markedly enhanced methamphetamine-induced dopamine release. Qualitatively similar findings were obtained when thioperamide was administered directly into the shell of the nucleus accumbens by reverse dialysis through the microdialysis probe, which indicates that the observed potentiation was not due to peripheral or pharmacokinetic interactions between the histamine $\mathrm{H} 3$ antagonists and methamphetamine. However, effects of intra-accumbal injection of thioperamide through the microdialysis probe were smaller than effects of systemic thioperamide, indicating that the observed potentiation was not exclusively mediated by histamine $\mathrm{H} 3$ receptors located in the nucleus accumbens.

Histamine $\mathrm{H} 3$ receptors on nondopaminergic neurons, located in striatal and nonstriatal areas of the brain might modulate dopamine neurotransmission and function and contribute to the observed interactions between methamphetamine and histamine $\mathrm{H} 3$ antagonists. It has been demonstrated, for example, that increased activity of $\mathrm{H} 3$ receptors may result in the inhibition of release of other neurotransmitters, like serotonin (Fink et al, 1990), norepinephrine (Di Carlo et al, 2000), glutamate (Doreulee et al, 2001), and GABA (Garcia et al, 1997). All of these systems are affected by methamphetamine administration, and they have extended connections with the dopaminergic system. Thus, it is likely that $\mathrm{H} 3$ receptor antagonists acting at the level of another neurotransmitter system may indirectly modulate the effects of methamphetamine on dopamine transmission. For example, histamine H3 heteroreceptors are located on serotonergic neurons (Leurs et al, 1998) and a role of the serotonergic neurotransmitter system in the modulation of the behavioral effects of methamphetamine is well established (eg Munzar et al, 1999b; Kuczenski et al, 1995). However, the significant effects of locally administered thioperamide on methamphetamine-induced dopamine transmission in the nucleus accumbens indicate a direct interaction of dopamine transmission with $\mathrm{H} 3$ receptors, likely located on dopaminergic nerve terminals (Schlicker et al, 1993; MolinaHernandez et al, 2000). Histamine acting at histamine H3 receptors presynaptically located on dopaminergic nerve terminals in the shell of the nucleus accumbens would, therefore, play an inhibitory role on dopaminergic transmission.

The cellular or molecular mechanism responsible for the potentiating effect of histamine $\mathrm{H} 3$ receptor antagonists on methamphetamine-induced dopamine release remains to be determined. Methamphetamine's effects on dopamine neurotransmission are the result of its ability to interact with a number of neurobiochemical processes important in the regulation of extracellular dopamine levels. Methamphetamine increases dopamine neurotransmission mainly by a nonexocytotic impulse-independent release of dopamine into the extracellular space, from an extravesicular, newly synthesized dopamine pool, reversing the direction of the dopamine transporter (DAT) (Kuczenski and Segal, 1994; Nishijima et al, 1996). Thus, methamphetamine's ability to increase extracellular dopamine levels depends on DAT functioning (Bennett et al, 1998; Metzger et al, 2000; Sandoval et al, 2001). Methamphetamine may also increase dopamine synthesis (Nishijima et al, 1996; Larsen et al, 2002), and dopamine-containing vesicles in the cytoplasm of dopamine neurons are affected by methamphetamine administration (Brown et al, 2002; Ugarte et al, 2003). Further, methamphetamine may interact with dopamine 
metabolism as a monoamine oxidase (MAO) inhibitor, reducing the ability of the MAO enzyme to metabolize dopamine and leading to an increase in dopamine levels (Suzuki et al, 1980). Histamine H3 antagonists interacting with any of these specific neurobiochemical targets could modulate the activity of methamphetamine on dopaminergic neurotransmission.

It has been demonstrated that histamine $\mathrm{H} 3$ receptors are $G$ protein receptors negatively coupled to adenylate cyclase and their stimulation by histamine results in decreased intracellular levels of cAMP (eg Lovenberg et al, 1999). Thus, it is likely that administration of both histamine $\mathrm{H} 3$ antagonists results in enhanced intracellular levels of cAMP, which could affect surface expression of the DAT or stimulate tyrosine hydroxylase activity. This explanation would be in line with reports that increased histamine levels (Ito et al, 1996) can inhibit dopamine synthesis by acting on $\mathrm{H} 3$ heteroreceptors on dopaminergic nerve terminals (Schlicker et al, 1993; Molina-Hernandez et al, 2000). Histamine $\mathrm{H} 3$ receptor antagonists might relieve these effects of endogenous histamine on dopamine synthesis, thus potentiating the methamphetamine-induced elevations in extracellular dopamine. This mechanism may explain the long lasting effects of methamphetamine after treatment with histamine $\mathrm{H} 3$ antagonists, but is unlikely to be responsible for immediate effects of this drug combination.

The immediate effects of histamine $\mathrm{H} 3$ antagonists on methamphetamine-induced dopamine release could be due in part to the increased intracellular availability of $\mathrm{Ca}^{2+}$ they produce, since activation of histamine $\mathrm{H} 3$ receptors has been suggested to inhibit the influx of $\mathrm{Ca}^{2+}$ (eg Endou et al, 1994; Leurs et al, 1995). Increased availability of $\mathrm{Ca}^{2+}$ may directly facilitate the release of dopamine and/or other neuromodulators that may indirectly enhance dopamine transmission. Increased availability of calcium might also play a role in the functioning and activity of DAT or tyrosine hydroxylase.

Although the underlying neurochemical mechanisms for observed interactions of histamine $\mathrm{H} 3$ receptors with methamphetamine remain speculative, the present findings point to histamine $\mathrm{H} 3$ receptors as a new and promising target for development of medications for the treatment of methamphetamine abuse, as well as other types of psychostimulant abuse. Several questions remain for future studies, in order to elucidate more fully interactions of methamphetamine with histamine $\mathrm{H} 3$ receptors. First, the effects of histamine $\mathrm{H} 3$ agonists on methamphetamineinduced behavioral and neurochemical effects remain to be studied. Second, it has to be determined whether the observed effects of histamine $\mathrm{H} 3$ antagonists are unique for methamphetamine or are more general for other drugs of abuse, especially cocaine, but also for drugs which do not directly interact with dopaminergic neurotransmission. Answers to these questions will help elucidate underlying neurobiochemical mechanisms for the potentiation of the behavioral and neurochemical effects of methamphetamine that were found in the present study.

\section{ACKNOWLEDGEMENTS}

We thank Drs Roy Wise, Sergi Ferre, and Marcello Solinas for their comments on earlier versions of the manuscript and Eric Thorndike for programming assistance. This study was supported by the Intramural Research Program of the National Institute on Drug Abuse, NIH, DHHS.

\section{REFERENCES}

Alheid GF, Heimer L (1988). New perspectives in basal forebrain organization of special relevance for neuropsychiatric disorders: the striatopallidal, amygdaloid, and corticopetal components of substantia innominata. Neuroscience 27: 1-39.

Arias-Montano JA, Floran B, Garcia M, Aceves J, Young JM (2001). Histamine $\mathrm{H}(3)$ receptor-mediated inhibition of depolarizationinduced, dopamine $\mathrm{D}(1)$ receptor-dependent release of [(3)H]gamma-aminobutryic acid from rat striatal slices. Br J Pharmacol 133: 165-171.

Arrang JM, Garbarg M, Schwartz JC (1983). Autoinhibition of histamine release mediated by a novel class (H3) of histamine receptor. Nature 302: 832-837.

Arrang JM, Garbarg M, Schwartz JC (1987). Highly potent and selective ligands for histamine H3-receptors. Nature 327: 117-123.

Bennett BA, Hollingsworth CK, Martin RS, Harp JJ (1998). Methamphetamine-induced alterations in dopamine transporter function. Brain Res 782: 219-227.

Brown JM, Riddle EL, Sandoval V, Weston RK, Hanson JE, Crosby MJ et al (2002). A single methamphetamine administration rapidly decreases vesicular dopamine uptake. J Pharmacol Exp Ther 302: 497-501.

Clapham J, Kilpatrick GJ (1994). Thioperamide, the selective histamine $\mathrm{H} 3$ receptor antagonist, attenuates stimulant-induced locomotor activity in the mouse. Eur J Pharmacol 259: 107-114.

Di Carlo G, Ghi P, Orsetti M (2000). Effect of R-(-)-alphamethylhistamine and thioperamide on in-vivo release of norepinephrine in the rat hippocampus. Prog Neuropsychopharmacol Biol Psychiatry 24: 275-284.

Di Chiara G, Tanda G, Bassareo V, Pontieri F, Acquas E, Fenu S et al (1999). Drug addiction as a disorder of associative learning. Role of nucleus accumbens shell/extended amygdala dopamine. Ann NY Acad Sci 877: 461-485.

Di Chiara G, Tanda G, Frau R, Carboni E (1993). On the preferential release of dopamine in the nucleus accumbens by amphetamine: further evidence obtained by vertically implanted concentric dialysis probes. Psychopharmacology 112: 398-402.

Doreulee N, Yanovsky Y, Flagmeyer I, Stevens DR, Haas HL, Brown RE (2001). Histamine $\mathrm{H}(3)$ receptors depress synaptic transmission in the corticostriatal pathway. Neuropharmacology 40: 106-113.

Endou M, Poli E, Levi R (1994). Histamine H3-receptor signaling in the heart: possible involvement of Gi/Go proteins and N-type $\mathrm{Ca}^{2+}$ channels. J Pharmacol Exp Ther 269: 221-229.

Ericson H, Blomqvist A, Kohler C (1989). Brainstem afferents to the tuberomammillary nucleus in the rat brain with special reference to monoaminergic innervation. J Comp Neurol 281: 169-192.

Esbenshade TA, Krueger KM, Miller TR, Kang CH, Denny LI, Witte DG et al (2003). Two novel and selective nonimidazole histamine h3 receptor antagonists a-304121 and a-317920: I. In vitro pharmacological effects. J Pharmacol Exp Ther 305: 887-896.

Fink K, Schlicker E, Neise A, Gothert M (1990). Involvement of presynaptic $\mathrm{H} 3$ receptors in the inhibitory effect of histamine on serotonin release in the rat brain cortex. Naunyn Schmiedebergs Arch Pharmacol 342: 513-519.

Garcia M, Floran B, Arias-Montano JA, Young JM, Aceves J (1997). Histamine $\mathrm{H} 3$ receptor activation selectively inhibits dopamine D1 receptor-dependent [3H]GABA release from depolarizationstimulated slices of rat substantia nigra pars reticulate. Neuroscience 80: 241-249. 
Goodchild RE, Court JA, Hobson I, Piggott MA, Perry RH, Ince P et al (1999). Distribution of histamine H3-receptor binding in the normal human basal ganglia: comparison with Huntington's and Parkinson's disease cases. Eur J Neurosci 11: 449-456.

Heimer L, Zahm DS, Churchill L, Kalivas PW, Wohltmann C (1991). Specificity in the projection patterns of accumbal core and shell in the rat. Neuroscience 41: 89-125.

Ito C, Onodera K, Sakurai E, Sato M, Watanabe T (1996). Effects of dopamine antagonists on neuronal histamine release in the striatum of rats subjected to acute and chronic treatments with methamphetamine. J Pharmacol Exp Ther 279: 271-276.

Ito C, Onodera K, Watanabe T, Sato M (1997). Effects of histamine agents on methamphetamine-induced locomotor hyperactivity and behavioral sensitization in rats. Psychopharmacology 130: 362-367.

Justinova Z, Ferre S, Segal PN, Antoniou K, Solinas M, Pappas LA et al (2003). Involvement of adenosine A1 and A2A receptors in the adenosinergic modulation of the discriminative-stimulus effects of cocaine and methamphetamine in rats. J Pharmacol Exp Ther 307: 977-986.

Komater VA, Browman KE, Curzon P, Hancock AA, Decker MW, Fox GB (2003). H3 receptor blockade by thioperamide enhances cognition in rats without inducing locomotor sensitization. Psychopharmacology 167: 363-372.

Koob GF (1992). Drugs of abuse: anatomy, pharmacology and function of reward pathways. Trends Pharmacol Sci 13: 177-184.

Krause M, Ligneau X, Stark H, Garbarg M, Schwartz JC, Schunack W (1998). 4-Alkynylphenyl imidazolylpropyl ethers as selective histamine H3-receptor antagonists with high oral central nervous system activity. J Med Chem 41: 4171-4176.

Kuczenski R, Segal DS (1994). Neurochemistry of amphetamine. In: Cho AK, Segal DS (eds). Amphetamine and its Analogs: Psychopharmacology, Toxicology and Abuse. Academic Press: San Diego. pp 81-113.

Kuczenski R, Segal DS, Cho AK, Melega W (1995). Hippocampus norepinephrine, caudate dopamine and serotonin, and behavioral responses to the stereoisomers of amphetamine and methamphetamine. J Neurosci 15: 1308-1317.

Larsen KE, Fon EA, Hastings TG, Edwards RH, Sulzer D (2002). Methamphetamine-induced degeneration of dopaminergic neurons involves autophagy and upregulation of dopamine synthesis. J Neurosci 22: 8951-8960.

Leurs R, Blandina P, Tedford C, Timmerman H (1998). Therapeutic potential of histamine $\mathrm{H} 3$ receptor agonists and antagonists. Trends Pharmacol Sci 19: 177-183.

Leurs R, Smit MJ, Timmerman H (1995). Molecular pharmacological aspects of histamine receptors. Pharmacol Ther 66: 413-463.

Lovenberg TW, Pyati J, Chang H, Wilson SJ, Erlander MG (2000). Cloning of rat histamine $\mathrm{H}(3)$ receptor reveals distinct species pharmacological profiles. J Pharmacol Exp Ther 293: 771-778.

Lovenberg TW, Roland BL, Wilson SJ, Jiang X, Pyati J, Huvar A et al (1999). Cloning and functional expression of the human histamine H3 receptor. Mol Pharmacol 55: 1101-1107.

Metzger RR, Haughey HM, Wilkins DG, Gibb JW, Hanson GR, Fleckenstein AE (2000). Methamphetamine-induced rapid decrease in dopamine transporter function: role of dopamine and hyperthermia. J Pharmacol Exp Ther 295: 1077-1085.

Molina-Hernandez A, Nunez A, Arias-Montano JA (2000). Histamine H3-receptor activation inhibits dopamine synthesis in rat striatum. Neuroreport 11: 163-166.

Morisset S, Pilon C, Tardivel-Lacombe J, Weinstein D, Rostene W, Betancur C et al (2002). Acute and chronic effects of methamphetamine on tele-methylhistamine levels in mouse brain: selective involvement of the $\mathrm{D}(2)$ and not $\mathrm{D}(3)$ receptor. J Pharmacol Exp Ther 300: 621-628.
Munzar P, Baumann MH, Shoaib M, Goldberg SR (1999a). Effects of dopamine and serotonin-releasing agents on methamphetamine discrimination and self-administration in rats. Psychopharmacology 141: 287-296.

Munzar P, Goldberg SR (1999). Noradrenergic modulation of the discriminative-stimulus effects of methamphetamine in rats. Psychopharmacology 143: 293-301.

Munzar P, Goldberg SR (2000). Dopaminergic involvement in the discriminative-stimulus effects of methamphetamine in rats. Psychopharmacology 148: 209-216.

Munzar P, Justinova Z, Kutkat SW, Ferre S, Goldberg SR (2002). Adenosinergic modulation of the discriminative-stimulus effects of methamphetamine in rats. Psychopharmacology (Berl) 161: 348-355.

Munzar P, Laufert MD, Kutkat SW, Novakova J, Goldberg SR (1999b). Effects of various serotonin agonists, antagonists and uptake inhibitors on the discriminative stimulus effects of methamphetamine in rats. J Pharmacol Exp Ther 291: 239-250.

Munzar P, Nosal R, Goldberg SR (1998). Potentiation of the discriminative-stimulus effects of methamphetamine by the histamine $\mathrm{H} 3$ receptor antagonist thioperamide in rats. Eur J Pharmacol 363: 93-101.

National Research Council (1996). Guide for the Care and Use of Laboratory Animals. National Academy Press: Washington, DC. Nishijima K, Kashiwa A, Hashimoto A, Iwama H, Umino A, Nishikawa T (1996). Differential effects of phencyclidine and methamphetamine on dopamine metabolism in rat frontal cortex and striatum as revealed by in vivo dialysis. Synapse 22: 304-312.

Paxinos G, Watson C (1986). The Rat Brain in Stereotaxic Coordinates. Academic Press: Sydney. 237pp.

Pillot C, Heron A, Schwartz JC, Arrang JM (2003). Ciproxifan, a histamine $\mathrm{H} 3$-receptor antagonist/inverse agonist, modulates the effects of methamphetamine on neuropeptide mRNA expression in rat striatum. Eur J Neurosci 17: 307-314.

Pollard H, Moreau J, Arrang JM, Schwartz JC (1993). A detailed autoradiographic mapping of histamine $\mathrm{H} 3$ receptors in rat brain areas. Neuroscience 52: 169-189.

Pontieri FE, Tanda G, Di Chiara G (1995). Intravenous cocaine, morphine, and amphetamine preferentially increase extracellular dopamine in the 'shell' as compared with the 'core' of the rat nucleus accumbens. Proc Natl Acad Sci USA 92: 12304-12308.

Prast H, Heistracher M, Philippu A (1993). Modulation by dopamine receptors of the histamine release in the rat hypothalamus. Naunyn Schmiedebergs Arch Pharmacol 347: 301-305.

Sandoval V, Riddle EL, Ugarte YV, Hanson GR, Fleckenstein AE (2001). Methamphetamine-induced rapid and reversible changes in dopamine transporter function: an in vitro model. J Neurosci 21: $1413-1419$.

Schlicker E, Fink K, Detzner M, Gothert M (1993). Histamine inhibits dopamine release in the mouse striatum via presynaptic H3 receptors. J Neural Transm Gen Sect 93: 1-10.

Stark H, Arrang JM, Ligneau X, Garbarg M, Ganellin CR, Schwartz JC et al (2001). The histamine H3 receptor and its ligands. Prog Med Chem 38: 279-308.

Stefanski R, Ladenheim B, Lee SH, Cadet JL, Goldberg SR (1999). Neuroadaptations in the dopaminergic system after active selfadministration but not after passive administration of methamphetamine. Eur J Pharmacol 371: 123-135.

Suzuki O, Hattori H, Asano M, Oya M, Katsumata Y (1980). Inhibition of monoamine oxidase by D-methamphetamine. Biochem Pharmacol 29: 2071-2073.

Tanda G, Pontieri FE, Di Chiara G (1997). Cannabinoid and heroin activation of mesolimbic dopamine transmission by a common mul opioid receptor mechanism. Science 276: 2048-2050. 
Tidey JW, Bergman J (1998). Drug discrimination in methamphetamine-trained monkeys: agonist and antagonist effects of dopaminergic drugs. J Pharmacol Exp Ther 285: 1163-1174.

Toyota H, Dugovic C, Koehl M, Laposky AD, Weber C, Ngo K et al (2002). Behavioral characterization of mice lacking histamine H(3) receptors. Mol Pharmacol 62: 389-397.
Ugarte YV, Rau KS, Riddle EL, Hanson GR, Fleckenstein AE (2003). Methamphetamine rapidly decreases mouse vesicular dopamine uptake: role of hyperthermia and dopamine D2 receptors. Eur J Pharmacol 472: 165-171.

Wise RA (1987). The role of reward pathways in the development of drug dependence. Pharmacol Ther 35: 227-263. 